\title{
The Decision to Start a New Firm: An Econometric Analysis of Regional Entrepreneurship in Tunisia
}

\author{
Islem Khefacha, Lotfi Belkacem and Fayçal Mansouri \\ Laboratory Research for Economy, Management and Quantitative Finance, IHEC - University of \\ Sousse, Sousse, Tunisia
}

\begin{abstract}
Understanding the factors that promote or mitigate transitions into self-employment is crucial to regional economic development efforts, while the number of new business created play a significant role to regional economic vitality and represent a major signal of a dynamic economy.

We use a new measure of firm formation based on the combination between individual background with effects depending on the regional context in Tunisia such as entrepreneurial human capital and labour force characteristics. Even though some of these factors have been the subject of several entrepreneurship studies, it is still difficult to identify which one impact significantly the decision to create a new firm.

As an illustration, the model is estimated using a data provided by the National Tunisian Global Entrepreneurship Monitor (GEM) 2010 Project, based on the analysis of a sample of 1966 cases.

The main findings of the study show that "competencies" measured by the two variables "knowing someone personally who started a business in the past 2 years" and "presence of good opportunities for starting a business" increase significantly the probability to create a new venture. In addition, we have found that the interaction between these two factors has a positive influence. However, "fear of failure" influences negatively the decision to start up. Finally, some fixed region-specific factors notably the average real wage of a region must be accounted for when estimating regional self-employment relationships.
\end{abstract}

We discuss the implications of our results for policy-makers with useful information in designing and implementing policies to promote enterprise development.

Keywords: Entrepreneurship, GEM, Generalized Least Squares, Tunisia.

\section{Introduction}

Entrepreneurship, as measured by selfemployment, has become an increasingly prominent characteristic not only for industrialized economies but also for nondeveloped economies. The efforts made to support entrepreneurship can be considered as strategy with potential to build an environment in which many people from all types of backgrounds can start up businesses.

The perceived importance of these roles in Tunisia is reflected in government programs designed to spur selfemployment, such as the Agency for the Promotion of Industry and Innovation 
(APII), the Company Creators and Business Incubation Centers (BIC), the enterprise incubators and the regional investment and development (RID). These programs constitute a support for any individual to become entrepreneurs by alleviating credit constraints, building programs, increasing awareness of innovations and business models, identifying and coaching talented people on designing their own business models etc.

However, there has been virtually no research looking at entrepreneurship at the regional level and so little attention has been paid to its determinants. Even though the absence of consensus on the definition of this field of study, a large number of researchers converge in the opinion that the creation of new venture in a primordial condition for a healthy economy. In fact, "an economy is healthy when it able to grow and create quality jobs for all residents, when low-income residents can obtain jobs that pay sufficient wages to support a family, when many people, regardless of their background or economic status, are able to mobilize the resources and expertise needed to start new businesses and when entrepreneurs work together so that all can succeed" (Holley, 2005). To transform the communities to this level of health, experts around the world suggest that we must focus on transforming the regional economies.

The purpose of the present paper is to develop an econometric model of regional entrepreneurship and to estimate the resulting self-employment function for Tunisian regions. We put essentially the accent on psychological models of entrepreneurial potential which consider that attitudes and perceptions may be more important than objective personal characteristics (Kruegar and Brazeal, 1994). Quite a long time, Evans and Leighton (1990) have suggested that economists might usefully incorporate in their models the many insights that are offered by the literature on entrepreneurship in sociology and psychology. For this, we draw on a number of previous theoretical studies to provide an analysis of such primary determinants and their corresponding effects, in an effort to map traits and characteristics of greatest relevance to start-up decision-making in the context of the entrepreneurial personality.

The paper is in four parts. First, the need for combining individual and regional characteristics to study Entrepreneurship is outlined. Secondly, the econometric model is specified and we discuss the data set and the variables to be used in the estimation. In the third part, the results of the estimation of the model is presented and discussed. The paper concludes with a summary of the findings and considers some implications for policy-makers particularly at the regional level.

\section{The Need for Combining Individual and Regional Characteristics to Study Entrepreneurship}

A central issue in the study of new venture creation is the reason behind the decision: why do some people plan to become entrepreneurs and others do not?

Amit and Muller (1994) had shown that the decision to start up a new enterprise is a process which is the fruit of two decisions: some new ventures are undertaken out of dissatisfaction with the current situation (Parker, 2004), whereas others are undertaken out of a desire to pursue an opportunity. However, researches on entrepreneurship showed that this decision exceed largely the perimeter of these two reasons. Hence, the decision to start a new venture may be influenced by experience and prior knowledge (Shepherd and DeTienne, 2005), social networks and contact to other entrepreneurs (Parker, 2004) and expected profit and success (Schumpeter, 1934; Knight, 1921).

From an economic perspective, an individual choose to become an entrepreneur when he expect that life-time utility from self-employment is higher than the life-time utility from paid-employment (Knight, 1921). Undoubtedly, the expected life-time utility is based not only on monetary determinants but also on nonmonetary returns like the individual's age, 
qualification, work experience, or risk propensity (Pamela, 2005).

Nevertheless, many people dream to become entrepreneurs, but seldom use or know how to access the resources they will need for success (Holley, 2005). Potential entrepreneurs on this scale require outside assistance notably in the region where they expect to create a new venture. According to Parker (2004), regions with strong entrepreneurial tradition over time and across generations may stimulate entrepreneurship.

Since different factors are interrelated, it is of particular interest to investigate the ceteris paribus impact of different variables affecting the decision to become self-employed as opposed to the decision to remain employed not only at the individual level but also at the regional level in Tunisia.

In this context, Institutional Economic Theory analyzed, in a holistic way, the contextual factors as determinants of entrepreneurship which can be formal or informal (Veciana et al., 2005). The former are related with some political and economic rules and the last with some codes of conduct, attitudes, values and norms of behavior. On the basis of this theory, Kruegar and Brazeal (1994) have developed an entrepreneurial potential model which draws upon not only Ajzen's Theory of Planned Behavior but also Shapero's work on the entrepreneurial event. This latter focuses on how the cultural and social environment affects the choice of an entrepreneurial path. It states that the intent to start a business derives from perceptions of both, desirability and feasibility.

Perceived desirability is tied to the perceptions of what important people in the individual's social surroundings would think about the launching a venture.

In the entrepreneurship literature, the role of pressure in decision-making has been studied mainly for persons and groups that the entrepreneur has close, frequent and intimate contacts. These key individuals including friends, family, and close business contacts which can actively support or not an entrepreneurial venture. Moreover, while demographic models have been criticized because they provide little insight on how family background and social forces shape the individual's decision process (Katz, 1992), entrepreneurship literature shows a strong relationship between the presence of role models in the family with new venture creation. Notably, an empirical research realized by Collins, Moore and Unwalla (1964) had shown that the influences over a new venture idea go back to the childhood and the family circumstances of the entrepreneur.

From another optic, several scholars have analyzed the relationship between gender and attitudes with new venture creation (Delmar and Davidsson 2000), and have found that males have a higher preference for entrepreneurship behavior than females. According to Hindle et al. (2009), it has been suggested that female entrepreneurs are disadvantaged compared to men with respect to most forms of human capital and also because of a lack of suitable and effective social networks.

Previous attempts have showed that a wide range of personality traits abilities with a distinct psychological profile strongly influences the anticipated utility (Wagner and Ziltener, 2008). Among personality traits common in entrepreneurs, we noticed a remarkable need for achievement (McClelland and Winter, 1969), a greater desire for independence (De Jong, 2009), the ability to innovate (Schumpeter, 1934) and the locus of internal control (Shapero, 1984). Persons with the last trait have the tendency to act autonomously under their own supervision and emphasize their own will, ability and actions in their professional life. This behavior is closely related with the trait of self-efficacy - as the belief in one's own ability to perform a given task (Shane, 2003) - where a high degree conduct peoples to see more opportunities than risks in certain situations. Hence, the fact that individuals see themselves as capable of carrying out the risk is related to the individual's perception of whether they perceive that 
they possess the necessary skills to initiate any tasks.

The second aspect of perception discussed in Kruegar and Brazeal's model is the "perceived ease or difficulty of performing the behavior of interest" (Ajzen, 1991).

This perception can be associated with the definition proposed by Venkataraman (1997) of the Entrepreneurship which is considered as "an activity that involves the discovery, evaluation and exploitation of opportunities to introduce new goods and services, ways of organizing markets, processes, and raw materials through organizing efforts that previously had not existed" (cited in: Shane, 2003).

It seems hence that resources and opportunities available to a person must to some extent dictate the decision to create or not a new venture. This concern is based on the presence of requisite resources and abilities which decrease obstacles or impediments anticipated by peoples and increase consequently the perceived control over the behavior. If insufficient control is perceived, the individual assesses the likelihood of reducing the discrepancy between the desired and actual state by procuring resources elsewhere, such as from a superior, colleague or supplier (De Jong, 2009).

From another point of view, Wagner and Ziltener (2008) showed that the situational character of start-up decisions is increasingly being emphasized within some body of theory originally conceived as a sub-discipline of neoclassical economics. In this context, Shapero (1984) emphasized the availability of some resources allowing to potential entrepreneur to create new project such as education, level of income or age.

For the first factor, there is a great deal of discussion and debate about the nature of impact of academic level in the decision to start up a new business. In fact, some research has provided contradictory evidence to the extent to which education can affect the step into self-employment. The relationship has been found to be either positive or negative, as well as insignificant (Parker, 2004). Even though empirical studies have not conclusively shown whether having a university degree increases the prospect of success of an entrepreneurial venture (Brüderl and Preisendorfer, 1998), some scholars showed that a high level of education is important to be competitive in today's market and individuals are more likely to exploit opportunities if they are better educated (Casson, 1995). This concern joins the empirical study of Yusuf (1995) while for Lee and Tsang (2001) a high level of education has a negative effect.

As for education, the impact of age on the decision to become an entrepreneur is either negative or positive according the studies made in this subject. In fact, thanks to their number of years accumulated for acquisition money and knowledge, elderly employees should possess relatively more human and physical capital needed for entrepreneurship. Thus, a positive relationship between entrepreneurship and age can be assumed (Parker 2004). Nevertheless, since the creation of a new venture bears the risk of failure and bankruptcy, persons close to retirement age will not start a business. In this case, we expect a negative impact when estimating the odds of becoming entrepreneurs for this range of age (Van Praag and van Ophem, 1995).

For the level of income, the relation with the decision of creation has been analyzed from different perspectives. Particularly, individuals with a high level of income can count on resources to implement the firm's needs, while for someone with a smaller income would prove difficult to achieve a new venture (Singh and Lucas, 2005). According to Audretsch (2002) and Gartner (1989), we consider that wage may have an influence on the availability of funding for the business project.

With these individual characteristics, the problematic of identifying which factors may influence the decision to create a new venture still not completed without the context in which the potential entrepreneur is involved. Assuming that some regions are more entrepreneurial 
than others, the question may be raised if a strong entrepreneurial tradition in a region affects the likelihood of individuals to become entrepreneurs. Particularly, regions with a high level of young population could stimulate individuals to start-up (Georgellis and Wall, 2000). The owner of this factor acts as role models and is important in creating and sustaining an entrepreneurial climate. As shown by several scholars, the age structure of the population can impact entrepreneurship through the likelihood of people of a certain age to become self-employed. Notably, Storey (2000) found since a long time that people between the age of 25 and 40 are most likely to become selfemployed.

Finally, we can't specify the determinants of entrepreneurship in a region by neglected the relationship between unemployment and self-employed even though the impact of unemployment on entrepreneurship is a contentious issue. In fact, on the one hand a high rate of unemployment in a region can serve as push factors to entrepreneurship because of a lack of opportunities in paidemployment. On the other hand, a high level of unemployment can also have a negative impact on entrepreneurship because it may coincide with a depressed economy and a lack of opportunities for entrepreneurship (Georgellis and Wall, 2000).

We have presented in the previously section some factors having autonomously a potential impact on the decision to create

$$
S_{i j}=\alpha+\beta_{1} w_{i j}+\beta_{2} w_{i j}^{2}+\gamma_{1} u_{i j}+\gamma_{1} u_{i j}^{2}+\delta^{\prime} X_{i j}+\rho^{\prime} Y_{i j}+\varepsilon_{i j}
$$

Where:

$S_{i j}$ is the difference in utility between self and paid-employment in a region $j$ for individual $i$.

$\boldsymbol{\alpha}$ is the individual-specific intercept.

$\boldsymbol{w}_{i j}$ is the average real wage for paidemployment in the region $j$ to which an individual $i$ belongs; new venture. However, the presence of certain conditions in isolation may not be enough. In the context of entrepreneurial decision-making, if one factor fails, the investment may in general become less likely. Consequently, it appears interesting to explore interaction effects between some factors. For example, De Jong (2009) showed that the connection between attitude and the decision to start-up may be stronger if other 'conditions' are met, i.e. if business owners perceive strong social support of their close ties, and feel that they are capable to successfully implement the opportunity. It seems that the opportunity exploitation may be stronger if two or more other factors are satisfied simultaneously.

Venkataraman (1997) added that the ability to make the connection between specific knowledge and a commercial opportunity requires a set of skills, aptitudes, insights, and circumstances that are neither uniformly nor widely distributed.

This concern reinforces the fact that the likelihood to create a new business may be increased or decreased with the presence of interaction between some factors.

\section{Data and Descriptive Statistics}

According to our theoretical approach, we can now advance the model permitted to estimate the relationship between series of social, demographic, cultural and socioeconomic factors in a region and selfemployed:

$\boldsymbol{u}_{i j}$ is the unemployment rate in the region $j$ to which an individual $i$ belongs;

$\boldsymbol{X}_{i j}$ is a vector of variables controlling for the characteristics of the labour force in the region $j$ to which an individual $i$ belongs;

$\boldsymbol{Y}_{i j}$ is a vector controlling for the characteristics of the individual $i$ in the region $j$.

$\boldsymbol{\varepsilon}_{i j}$ is an error term. 
Define a random variable $s_{i}$ such that $\boldsymbol{s}_{\boldsymbol{i}}=\mathbf{1}$ if individual $i$ in region $j$ is self-employed, and $\mathbf{s}_{\mathbf{i}}=\mathbf{0}$ otherwise. If individual $i$ was randomly selected from region $j$, the probability that he will be self-employed is:

$$
\operatorname{Pr}\left[s_{i j}=1\right]=\operatorname{Pr}\left[U_{i j}^{s e}-U_{i j}^{p e}+\xi_{\mathrm{ij}} \succ 0\right]
$$

For region $j$ 's mean person, the difference in utility between self- and paidemployment in region $j$ is $U_{i j}^{s e}-U_{i j}^{p e}+\xi_{\mathrm{ij}}$ where differentiates the mean person in region $j$ from the mean person of the country as a whole. $\xi_{i}$ differs across regions because of regional difference in average education levels, age, entrepreneurial human capital, and other individual characteristics, some of which may not be observable nor measurable (Georgellis and Wall, 2000).

Among variables that capture these differences we note the region's wage for paid-employment and its unemployment rate. As these two labour market variables have two opposing effects on entrepreneurship, we have used a quadratic form (Georgellis and Wall, 2000). This procedure allow for the possibility that the recession-push effect dominates for some range of unemployment rates, whereas the prosperity-pull effect dominates for another range. As well as the previous factor, the quadratic form used to estimate the real wage in a region allows handling both the two opposing effects: the measures of the pecuniary benefits of paidemployment (the opportunity cost of being an entrepreneur) and the measure of level of income of self-employed, and therefore act as a proxy for the level of regional aggregate demand.

Other variables represented by vector $\boldsymbol{X}_{\boldsymbol{i}}$ concerns the region's suitability for entrepreneurs, as measured by the characteristics of the labour force notably the share of a region's population aged 1844 and the share aged 44 to retirement age.

Table 1: Average Self-Employment Rates, Labour Market Variables, and Labour Force Characteristics

\begin{tabular}{|l|c|c|c|c|}
\hline Region & Unemployment rate & $\begin{array}{c}\text { Average wage } \\
\text { (TDN) }\end{array}$ & $\begin{array}{c}\text { \% aged } \\
\mathbf{1 8 - 4 4}\end{array}$ & $\begin{array}{c}\text { \% aged } \\
\text { 44-retirement }\end{array}$ \\
\hline Greater Tunis & $20 \%$ & 3425 & $73,24 \%$ & $26,76 \%$ \\
\hline North East & $22 \%$ & 1559 & $69,29 \%$ & $30,71 \%$ \\
\hline North West & $32 \%$ & 985 & $58,92 \%$ & $41,08 \%$ \\
\hline Center East & $18 \%$ & 2000 & $72,95 \%$ & $27,05 \%$ \\
\hline Center West & $40 \%$ & 1054 & $71,54 \%$ & $28,46 \%$ \\
\hline South East & $38 \%$ & 547 & $70,17 \%$ & $29,83 \%$ \\
\hline South West & $35 \%$ & 422 & $66,67 \%$ & $33,33 \%$ \\
\hline
\end{tabular}

Finally, variables represented by vector $Y_{i}$ have been provided by the National Tunisian Global Entrepreneurship Monitor 2010 Project:

\section{- Perception of Skills, Knowledge and} Experience: This variable indicate whether the individual sees themselves as having the ability to create a new business or not. This perception was gauged in the questionnaire by asking: "Do you have the knowledge, skill and experience required to start a new business?"

- Relations with Entrepreneurs: This variable is measured using the question "Do you know someone personally who started a business in the past 2 years?", and indicates whether an individual is 
acquainted with an entrepreneur or not. This variable is related to the perception of the viability of creating a business.

- Perception of Opportunities: This variable, which is also dichotomy, tells us directly whether the individual does or doesn't perceive the existence of business opportunities in the local area through the question "In the next six months there will be good opportunities for starting a business in the area where you live?"

- Fear of Failure: This variable shows whether an individual is afraid of failing in the creation of a new business. It can be considered as an approximate measurement of the aversion to risk. The question related to this item is "Fear of failure would prevent you from starting a business?" It is important to point out that overconfidence can reduce the fear of failure to a certain extent.

- Academic Level: This variable presents the following categories: pre-primary education, primary education, lower secondary, upper secondary, postsecondary, first stage of tertiary and second stage of tertiary.

For reference, Table 1 and 2 provides descriptive statistics related with all the variables included in our econometric model.

As to handle the possibility of nonspherical error terms, we used Generalized Least Squares (Greene, 1997) to estimate equation (1) as recommended by Georgellis and Wall (2000). This econometric procedure of estimation allows correcting for within-region heteroshedasticity and cross-region correlation (Anselin, 1988). The latter of these arises when there is cross correlation of regional disturbance terms, due either to spatial autocorrelation or because regions have similar responses to shocks, even if they are not otherwise spatially related.

The Main Findings of the Econometric Study: The Impact of Both Regional and Individual Characteristics on Entrepreneurship

On the basis of the econometric model, we can now analyze the variations of the variable "individual $i$ in region $j$ is selfemployed or not" with two modalities in the setting of a logistical model.

In other words, for each of the independent variables, we tried to express a measure of its influence on the occurrence of the corresponding event of the dependant variable. These influences are called main effects of variables while the particular combinations of modalities of independent variables correspond to the interaction effects (DeMaris, 1992).

Table 3 presents the results. The goodnessof-fit of logistic regression models is assessed by comparing the transformed loglikelihood value with the previous model. The difference between both values follows a $\mathrm{X}^{2}$ distribution and may be tested accordingly (Verbeek, 2004). 
Table 2: Variables and Descriptive Statistics $(n=1966)$

\begin{tabular}{|c|c|}
\hline Variables & Statistics \\
\hline Skills, knowledge and experience & Yes $=53.1 \% ;$ No $=46.9 \%$ \\
\hline Fear of failure & Yes $=25.9 \% ;$ No $=74.1 \%$ \\
\hline Knows someone & Yes $=58 \% ;$ No $=42 \%$ \\
\hline Advice & Yes $=38.9 \% ;$ No $=61.1 \%$ \\
\hline Gender & $\begin{array}{l}\text { Male }=48.8 \% \\
\text { Female }=51.2 \%\end{array}$ \\
\hline Opportunities & Yes $=36.8 \% ; \mathrm{No}=63.2 \%$ \\
\hline Academic level & $\begin{array}{l}\text { Pre-primary education }=6.1 \% \\
\text { Primary education }=19.1 \% \\
\text { Lower secondary }=10.1 \% \\
\text { Upper secondary }=33.3 \% \\
\text { Post-secondary }=17.6 \% \\
\text { First stage of tertiary }=19.9 \% \\
\text { Second stage of tertiary }=3.8 \%\end{array}$ \\
\hline Age & $\begin{array}{l}18-24=20.2 \% \\
25-34=28.1 \% \\
35-44=22 \% \\
45-54=17.9 \% \\
55-64=11.8 \%\end{array}$ \\
\hline Region & $\begin{array}{l}\text { Greater Tunis }=24 \% \\
\text { North East }=14 \% \\
\text { North West }=12.2 \% \\
\text { Center East }=22.5 \% \\
\text { Center West }=12.7 \% \\
\text { South East }=9.1 \% \\
\text { South West }=5.6 \%\end{array}$ \\
\hline $\begin{array}{l}\text { Individual } i \text { in region } j \text { is self- } \\
\text { employed or not }\end{array}$ & Yes $=15.1 \% ;$ No $=84.9 \%$ \\
\hline
\end{tabular}

The first model was an empty model (estimating only the intercept) permitting to obtain baseline values for the loglikelihood.

The second model added the control variables to the equation in order to isolate the effect of these variables to the start-up decision: gender, academic level, age and region to which individual belong.

As Delmar and Davidsson (2000) study, we found that males have a higher preference for entrepreneurship behavior than females. As well, the relationship between the academic level and entrepreneurship is positive which joins the empirical study of Yusuf (1995) showing that a high level of education is important to be competitive in today's market and individuals are more likely to exploit opportunities if they are better educated (Casson, 1995).

In the third model, we entered the main planned behavior constructs combined with regional characteristics. Goodness-offit improved significantly $(\Delta-2 L L=73.191$ with $p<0.01$ ).

From the Wald tests, we conclude that as for gender, the role of pressure in decisionmaking related mainly with groups that the entrepreneur has frequent and intimate contacts; a strong and positive connection with the decision to start-up a new venture is noted. This implies that key individuals including friends, family, and close 
business contacts support an entrepreneurial venture.

As well as for the last two variables, the fact to "know someone personally who started a business" and the perception that in the next six months there will be good opportunities for starting a business in the area where an individual live increase significantly the probability to become selfemployed. On the contrary, fear of failure are negatively related to the decision to start-up which support the theoretical approach showing that an individual is afraid of failing in the creation of a new business. Besides, we found that the average of wage in a region impact significantly but negatively the choice between self-employed and paid-employed. In effect, the average wage in Tunisian region doesn't encourage individual to become entrepreneur.

On the other hand, following Jaccard's (2001) recommendation of hierarchically well-formulated models, the fourth model contained all two and three-way interactions between attitude, subjective norm and perceived behavioral control. Among the different way interactions, the two-way interaction between knowing someone personally who started a business in the past 2 years and presence of good opportunities for starting a business in the area where potential entrepreneur lives increases significantly the odds of start-up.

Table 3: Binary Logistic Regression Models (n=1966)

\begin{tabular}{|c|c|c|c|c|}
\hline \multicolumn{5}{|c|}{ Models } \\
\hline & I & II & III & IV \\
\hline \multicolumn{5}{|l|}{ Effect parameters : } \\
\hline Constant & $1.730^{*}$ & 0.103 & 0.187 & 0.147 \\
\hline Academic level & & $0.018^{*}$ & $0.021^{*}$ & $0.019^{*}$ \\
\hline Age & & 0.011 & $0.014^{* *}$ & $0.014^{*}$ \\
\hline Gender & & $0.160^{*}$ & $0.102^{*}$ & $0.101^{*}$ \\
\hline Greater Tunis & & -0.031 & -0.032 & -0.029 \\
\hline North East & & 0.013 & 0.021 & 0.022 \\
\hline North West & & 0.011 & 0.019 & 0.021 \\
\hline Center East & & -0.009 & 0.005 & 0.006 \\
\hline Center West & & 0.062 & $0.073^{\wedge}$ & $0.071^{\wedge}$ \\
\hline South East & & -0.023 & -0.008 & -0.004 \\
\hline Unemployment rate & & & -76.556 & -75.150 \\
\hline Square of unemployment rate & & & 118.779 & 116.451 \\
\hline Real wage & & & $-0.002^{* *}$ & $-0.002^{* *}$ \\
\hline Square of real wage & & & $2.541 \mathrm{E}-7^{\wedge}$ & $2.541 \mathrm{E}-7^{\wedge}$ \\
\hline$\%$ aged $18-44$ & & & -3.558 & -3.518 \\
\hline$\%$ aged 44-retirement & & & -3.557 & -3.517 \\
\hline Skills. knowledge and experience (S) & & & $0.126^{*}$ & 0.106 \\
\hline Fear of failure (F) & & & $-0.073^{*}$ & $-0.139 *$ \\
\hline Knows someone $(\mathrm{K})$ & & & $0.039 * *$ & 0.071 \\
\hline Opportunities (0) & & & $0.075^{*}$ & 0.088 \\
\hline $\mathrm{S}^{*} \mathrm{~F}$ & & & & 0.105 \\
\hline $\mathrm{S}^{*} \mathrm{~K}$ & & & & -0.059 \\
\hline $\mathrm{S}^{*} \mathrm{O}$ & & & & -0.047 \\
\hline $\mathrm{F}^{*} \mathrm{~K}$ & & & & 0.019 \\
\hline $\mathrm{F}^{*} \mathrm{O}$ & & & & 0.007 \\
\hline $\mathrm{O}^{*} \mathrm{~K}$ & & & & $0.023^{* *}$ \\
\hline $\mathrm{S}^{*} \mathrm{~K}^{*} \mathrm{O}$ & & & & 0.073 \\
\hline $\mathrm{S}^{*} \mathrm{~F}^{*} \mathrm{O}$ & & & & 0.015 \\
\hline $\mathrm{F}^{*} \mathrm{~K}^{*} \mathrm{O}$ & & & & -0.191 \\
\hline \multicolumn{5}{|l|}{ Model fit: } \\
\hline Log-likelihood & $-721,791$ & -654.041 & -580.846 & -579.302 \\
\hline \multicolumn{5}{|l|}{ significance } \\
\hline${ }^{*} \mathrm{p}<0.01$ ** $^{* *} \mathrm{p}<0.05 ;^{\wedge} \mathrm{p}<0.10$ & & & & \\
\hline
\end{tabular}




\section{Concluding Remarks}

This paper tested the role of both individual and regional characteristics as a stimulus for launching a new venture. It focuses explicitly on various determinants influencing the entrepreneurial decision in Tunisia at a regional level. In fact, knowing that regional characteristics have a pronounced effect on the survival and success of new businesses, individual preferences and attitudes may be analyzed by linking regional characteristics.

To this end, we estimate a novel model of entrepreneurial choice econometrically using GEM data. Our findings confirm that the decision to create new venture is not just a matter of either 'like' or 'ability'. Results suggest the decision to become an entrepreneur is best explained by a composite of some factors, notably "knowing someone personally who started a business in the past 2 years" and "presence of good opportunities for starting a business". Start-up is much more likely when these two factors are satisfied simultaneously.

This can contribute to a better understanding of entrepreneurial psychology in a manner potentially valuable to efforts to structure and design entrepreneurial decision. However, it is important to point out that these characteristics can also be found in individuals that are not entrepreneurs and it cannot thus be regarded as an exclusively entrepreneurial characteristic (Gartner 1989). For this, the integration of some regional characteristics in the econometric model can advise stakeholders about the factors they should look for when deciding whether and how to offer support to a potential entrepreneur. Notably the average of wage in a region constitutes a determinant factor for the decision to become self-employed.

We draw several policy implications from these results. First, we must pay attention that after the exam of how some determinants having a crucial impact on the decision to create new business, we need to focus on the constraints that might limit entrepreneurs in making their own choice. These constraints are notably related to the external and institutional environment in terms of policies, reforms or geographical localization. Second, our results give some novel support to current Tunisia policies of targeting regional assistance programs. Third, benefits from business assistance programs must take into account the regional heterogeneity when stimulating self-employment.

Further research is needed on what is the composition of the networks around entrepreneurs (e.g. family, professional, etc; and specifically relations with researchers and government agencies), and how are the entrepreneurs networking, together with other conditions such as riskaversion, affecting their growthexpectation, in the national context, including a moderating effect from national values?

\section{References}

Ajzen, I. (1991). "The Theory of Planned Behavior," Organizational Behavior and Human Decision Processes, 50, 179-211.

Amit, R. \& Muller, E. (1994). 'Push and Pull Entrepreneurship, Frontiers of Entrepreneurship Research,' Bygrave, $W_{\text {., et }}$ al., (ed) Babson College, Wellesley.

Audretsch, D. B., Thurik, R., Verheul, I. \& Wennekers, S. (2002). "Entrepreneurship: Determinants and Policy in a European-US Comparison," Boston/Dordrecht: Kluwer Academic Publishers.

Bruderl, J. \& Preisendorfer, P. (1998). "Network Support and the Success of Newly Founded Businesses," Small Business Economics, 10, 213-225.

Casson, M. (1995). Entrepreneurship and Business Culture, Aldershot, UK: Edward Elgar.

Collins, O. F., Moore, D. G. \& Unwalla, D. B. (1964). 'The Enterprising Man,' MSU Business Studies, Bureau of Business and Economic Research, Graduate School of 
Business Administration, Michigan State University, East Lansing, Michigan.

De Jong, J. P. J. (2009). "The Decision to Innovate: Antecedents of Opportunity Exploitation in High Tech Small Firms," Working paper, January.

Delmar, F. \& Davidsson, P. (2000). "Where Do They Come from? Prevalence and Characteristics of Nascent Entrepreneurs," Entrepreneurship and Regional Development, 12, 1-23.

Evans, D. S. \& Leighton, L. S. (1990). “Small Business Formation by Unemployed and Employed Workers," Small Business Economics, 24, 319-330.

Gartner, W. B. (1989). 'Some Suggestions for Research on Entrepreneurial Traits and Characteristics,' Entrepreneurship: Theory \& Practice, 14, 27-37.

Georgellis, Y. \& Wall, H. J. (2000). "What Makes a Region Entrepreneurial? Evidence from Britain," Annals of Regional Science, 34(3), 385-403.

Hindle, K., Klyver, K. \& Jennings, D. F. (2009). "An Informed Intent Model: Incorporating Human Capital, Social Capital, and Gender Variables into the Theoretical Model of Entrepreneurial Intentions," Understanding the entrepreneurial mind. Eds. A. Carsrud and M. Brännback, New York, 35-50.

Holley, J.. (2005). "Building a Regional Entrepreneurship Network: A Guide to Action," [online], [Retrieved December 29, 2011],

http://www.networkweaving.com/june_fil es/HowToREN.pdf.

Jaccard, J. (2001). Interaction Effects in Logistic Regression, Sage: Thousand Oaks, CA.

Katz, J. A. (1992). 'A Psychosocial Cognitive Model of Employment Status Choice,' Entrepreneurship, Theory and Practice, 171, 29- 37.

Knight, F. H. (1921). Risk, Uncertainty, and Profit, Houghton Mifflin.
Kruegar, N. \& Brazeal, D. (1994). "Entrepreneurial Potential and Potential Entrepreneurs," Entrepreneurship, Theory and Practice, 18, 91-104.

Lee, D. Y. \& Tsang, E. W. K. (2001). "The Effects of Entrepreneurial Personality, Background and Network Activities on Venture Growth," Journal of Management Studies, 38, 583-602.

McClelland, D. C. \& Winter, D. G. (1969). 'Motivating Economic Achievement: Accelerating Economic Development through Psychological Training,' New York: Free Press.

Opie, R. \& Schumpeter, J. A. (1934). 'The Theory of Economic Development: An Inquiry into Profits, Capital, Credit, Interest, and the Business Cycle,' Cambridge,

Pamela, M. (2005). "Entrepreneurship in the Region: Breeding Ground for Nascent Enterpreneurs?," Freiberg working papers, No. 05,[online], http://hdl.handle.net/10419/27091.

Parker, S.- C. (2004). "The Economics of Self-Employment and Entrepreneurship," Cambridge: Cambridge University Press.

Shane, S. A. (2003). A General Theory of Entrepreneurship: The IndividualOpportunity, Nexus.Boston, MA: Edward Elgar.

Shapero, A. (1984). 'The Entrepreneurial Event,' In Calvin A. Kent Ed., The environment for entrepreneurship: 21-40. Toronto, MA: Lexington Books.

Shepherd, D. A. \& De Tienne, D. R. (2005). "Prior Knoweldge, Potential Financial Rewards, and Opportunity Identification," Entrepreneurship Theory and practice, 291, 91-112.

Singh, R. P. \& Lucas, L. M. (2005). "Not Just Domestic Engineers: An Exploratory Study of Homemaker Entrepreneurs," Entrepreneurship Theory and Practice, 29, 79-90. 
Storey, D. J. (2000). "Six Steps to Heaven, Evaluating the Impact of Public Policies to support Small Businesses in Developed Economies," In D.L. Sexton and H. Landstrom eds., Handbook of Entrepreneurship. Blackwells, Oxford, 176194.

Stuart, R. W. \& Abetti, P. A. (1990). "Impact of Entrepreneurial and Management Experience on Early Performance," Journal of Business Venturing, 5, 151-162.

Van Praag, M. C. \& Van Ophem, H. (1995). "Determinants of Willingness and Opportunity to Start as an Entrepreneur," Kyklos, 4, 513-540.

Veciana, J. M., Aponte, M. \& Urbano, D. (2005). 'University Students' Attitudes towards Entrepreneurship: A Two Countries Comparison," International Entrepreneurship and Management Journal, 1, 165-182.

Venkataraman, S. (1997). "The Distinctive Domain of Entrepreneurship Research: An Editor's Perspective," Advances in Entrepreneurship. JAI Press, 3, 119-138.

Wagner, K. \& Ziltener. A. (2008). 'The Nascent Entrepreneur at the Crossroads: Entrepreneurial Motives as Determinants for Different Types of Entrepreneurs,' Discussion Papers on Entrepreneurship and Innovation, Swiss Institute for Entrepreneurship.

Yusuf, A. (1995). 'Critical Success Factors for Small Business: Perceptions of South Pacific Entrepreneurs,' Journal of Small Business Management, 33, 68-73. 